Volume 2

Number 1 Secrecy and Intelligence

September 2018

\title{
Writing the Official History of the Joint Intelligence Committee
}

Michael Goodman

King's College London, michael.s.goodman@kcl.ac.uk

Follow this and additional works at: https://scholarworks.sjsu.edu/secrecyandsociety

Part of the Defense and Security Studies Commons, Diplomatic History Commons, Military History Commons, and the Political History Commons

\section{Recommended Citation}

Goodman, Michael. 2018. "Writing the Official History of the Joint Intelligence Committee." Secrecy and Society 2(1). https://doi.org/10.31979/2377-6188.2018.020109

https://scholarworks.sjsu.edu/secrecyandsociety/vol2/iss1/9

This Special Issue Article is brought to you for free and open access by the School of Information at SJSU ScholarWorks. It has been accepted for inclusion in Secrecy and Society by an authorized administrator of SJSU ScholarWorks. For more information, please contact scholarworks@sjsu.edu. 


\title{
Writing the Official History of the Joint Intelligence Committee
}

\author{
Abstract \\ This article recounts the experience of a professional historian in being given the keys to \\ the kingdom: access to the classified vaults of Britain's Joint Intelligence Committee. This \\ article includes some of the problems in having access, but complying with the sensitivities \\ around official accounts, difficulties in writing a global history, or trying to make the work \\ of a committee interesting and accessible, and of trying to determine the impact of \\ intelligence on policy.
}

\section{Keywords}

Britain, Cold War, espionage, Former Soviet Union, intelligence, Joint Intelligence Committee, public policy, spying, United States 


\title{
Writing the Official History of Britain's Joint Intelligence Committee
}

Michael S. Goodman

\begin{abstract}
This article recounts the experience of a professional historian in being given the keys to the kingdom: access to the classified vaults of Britain's Joint Intelligence Committee. This article includes some of the problems in having access, but complying with the sensitivities around official accounts, difficulties in writing a global history, or trying to make the work of a committee interesting and accessible, and of trying to determine the impact of intelligence on policy.
\end{abstract}

\section{Keywords}

Britain, Cold War, espionage, Former Soviet Union, intelligence, Joint Intelligence Committee, public policy, spying, United States

Britain is one of the few countries in the world which has had an Official History programme. Created in the aftermath of the Boer War at the beginning of the twentieth century, it was initially designed to provide historians with access to recently used papers in order to provide lessons for future conflicts. The series expanded following the Second World War to include non-military topics. Unfortunately, the austerity of recent years has led to the closing of the programme within the Cabinet Office, with the final few histories now approaching completion. ${ }^{1}$ As one of the last Official Historians, I thought it would be interesting to reflect upon my experiences: 
Secrecy and Society, Vol. 2, No. 1 [2018], Art. 9

The first volume of the Official History of the Joint Intelligence Committee (JIC) was published in 2014, with the second volume due to appear in $2018 .^{2}$

Historically speaking, academics have treated officialdom with some scepticism. The nineteenth century Regius Professor of Modern History Lord Acton declared that there is "an enmity between the truth of history and the reason of state, between sincere quest and official secrecy." ${ }^{3}$ Similarly, Sir Herbert Butterfield, a Cambridge historian, stated that "we must never lose sight of the separate interests of officialdom on the one hand and the academic historian on the other, never allow the situation to be blurred or the tension and conflict between the two to be quietened." ${ }^{4}$ Butterfield's attack, in particular, was scathing and almost certainly based on various personal experiences with official historians. ${ }^{5}$

The issue, of course, is one of sources. Official Historians have unparalleled and unlimited access to files which have not yet been released, and which, quite possibly, will never be released. The issue is one identified by Hugh Trevor-Roper (later Lord Dacre), who said, "when a historian relies mainly on primary sources, which we cannot easily check, he challenges our confidence and forces us to ask critical questions. How reliable is his historical method? How sound is his judgment?" ${ }^{\prime \prime}$ Indeed, as a colleague of mine, Professor Rodney Lowe (Official History of the Civil Service) once wrote, there are two reactions from professional historians to official 
historians: either "contempt on the grounds that it is mere propaganda," or "a guarded interest." Arguably, neither is what the government has had in mind when commissioning such accounts.

A related category of book is the "authorised history." Whilst both Christopher Andrew and Keith Jeffery, in their respective accounts of MI5 and MI6, produced "authorised" and not "official" accounts, the difference is somewhat semantic. ${ }^{8}$ In a similar vein, the multi-volumes that Christopher Andrew wrote with the Russian defectors Oleg Gordievsky in the 1990s, or Vasili Mitrokhin in the 2000s, were also based on privileged access to unreleased files. Again, the professional or armchair historian is being asked to place their trust in the analysis of someone whose archival base cannot be independently verified. A related but slightly different work will be the forthcoming "authorised" history of GCHQ, written by a Canadian professor, John Ferris. Ferris is an obvious choice, given his long pedigree in writing on SIGINT matters, but unlike the MI5, MI6, or JIC histories, Ferris is not being granted a free run of the archives and will, instead, only be able to digest files that are fed to him. ${ }^{9}$

How does this impact upon writing the history of the JIC, whose records have been partially declassified in line with the thirty-year rule? Well, firstly, what is the Joint Intelligence Committee? Very briefly, it is-in the words of one former Chairman-the "final arbiter of intelligence." The JIC sits at the apex of British intelligence, providing assessments to 
Secrecy and Society, Vol. 2, No. 1 [2018], Art. 9

policymakers but also looking down upon the intelligence community below it, setting requirements, and coordinating intelligence. In a sense, then, its assessments present a picture of how the British government's policies have spanned the decades. ${ }^{10}$

The first volume covers the period from its conception in 1936 to the Suez Crisis in 1956. There are several complicating factors here, aside from the breadth of the history itself:

1) The first is the range of topics. Anyone who has studied the JIC's records will have noted just how broad its remit was. This was, and indeed is, a committee that produces assessments, both long-term and immediate; it has a management function; it sets collection requirements and priorities; it deals with security matters, and the clearance of books-the list is endless. The difficultly is conveying the worldwide remit of the JIC into chapters that, generally speaking, focus on specific topics.

2) A second difficulty is knowing what exactly to include under the JIC umbrella. The full Committee had, at various points in the past, a large number of sub-committees that were subordinate to it; furthermore, there were a number of regional JICs that reported back to London. ${ }^{11}$ This is particularly the case with the Chairman. Being JIC Chairman has never been seen as a full-time position. For the majority of the cold war, it was held by a Foreign Office incumbent, who combined the post with heading up the Permanent Under-Secretary's Department. At other points, this position was 
removed, and they also headed the Cabinet Office's "Overseas and Policy Directorate," or acted as the Prime Minister's advisor on foreign matters. So, how can these roles-which both impacted on and were influenced by the JIC-work, be excluded, or be ignored? It is not an easy task.

3) A third complicating factor is the fact that this is a Committee. Let me illustrate what I mean. In the late 1960s, the Secretary wrote, in his published memoir, about the science of minute writing. He referred to how the minutes produced would not, necessarily, reflect the discussions in the Committee. The Chairman's introduction and summing up would often be invented afterward, and even "sometimes after particularly turbulent debate, we were forced to minute what we thought the members intended to say, rather than what they actually said. ${ }^{12}$ How, then, can the records alone be relied upon?

4) A bigger issue, and one that returns us to the starting comments on Official History, is the documentary trail of the JIC. A practical problem is the sheer volume of information, though there is perhaps nothing new here. More serious is the nature of the paperwork itself: As anyone who has studied the JIC's records will know, this is not an easy task. A trap always at the back of my mind is to avoid the criticism addressed at Sir Harry Hinsley's Official Histories: that they were books about committees, written by committees and for committees. ${ }^{13}$ 
Secrecy and Society, Vol. 2, No. 1 [2018], Art. 9

The Committee's different functions are reflected in the nature of the released material. Though it changes slightly over time, generally speaking, the material is organised in various ways: There are volumes of Committee minutes and memoranda; separate volumes containing the JIC Secretary's paperwork; subject-specific files; volumes of Confidential Annexes, essentially the code-word stuff that is too secret for the normal, already highly-secretive volumes; and the more tactical-focussed assessments, including the short-lived "Weekly Summary of Current Intelligence," which was replaced by two weekly publications-the "Weekly Review of Current Intelligence" (the Grey Book) and the "Weekly Survey of Intelligence" (the Red Book). The Grey Book was intended for a fairly wide distribution, whereas the Red Book expanded on selected items of current intelligence at higher levels of classification and had a much more limited distribution. ${ }^{14}$

What is the status of these records? The majority of the minutes and memoranda have been declassified, and these provide a very good picture of how the assessments changed over time. Some of the JIC secretariat files have been released, though the majority have not. In addition, none of the Confidential Annex volumes have been declassified. Some of the Weekly Review of Current Intelligence volumes have been released, but none of the more classified Weekly Survey of Intelligence have been. Having looked at all these files, I think it is fair to say that although the assessments generally don't change, you do get more specific information in the retained 
volumes. Furthermore, there are some topics discussed in them which are not revealed in the declassified files. Here, to whet your appetite, is the opening paragraph from my book The Official History of the Joint Intelligence Committee: Volume I, From the Approach of the Second World War to the Suez Crisis:

On Tuesday 7 July 1936, a few weeks before the spectacular opening by Adolf Hitler of the Berlin Olympics, seven men sat around a large ornate table in a four storey building just opposite the entrance to Downing Street to discuss what was known of the growing military challenge that Germany posed for the British Empire. Six of the men were officers representing the intelligence staffs of the Royal Navy, Army and Royal Air Force. The seventh was a shadowy civilian whose background was in an organisation that had then no official existence, the Secret Intelligence Service. The building in which the meeting was taking place, No. 2 Whitehall Gardens, had made history before when an earlier occupant, Benjamin Disraeli, had held meetings of his Cabinet there. Now the large ornate rooms, modelled in the French style similar to the interior of the Palace at Versailles, housed the Committee of Imperial Defence (CID) and the Chiefs of Staff (COS) Committee and it was at their direction that the key figures in British intelligence were meeting formally in committee for the first time. Outside the storm clouds gathered and as the clock chimed 11 o'clock in the Secretary's Room on the first floor the chairman, a Brigadier in the East Yorkshire Regiment, opened proceedings. The Joint Intelligence Committee had come into being. ${ }^{15}$

The first volume of the Official History covers a twenty-year period, from the JIC's creation in 1936 to its involvement in the Suez crisis of 1956. The JIC was born out of the anxieties over the military rise of Nazi Germany; it reached maturity in dealing with the very different concerns of the Cold War and the threat of nuclear annihilation. As it developed its own personality, the JIC became a key component in British and allied politico- 
military debates. It was responsible for the invention of modern all-source intelligence assessment, as we know it in Britain today, and the development of intelligence analysis as a function supporting government as a whole and not just the naval, military, and air staffs. It brought military planners to a greater appreciation of the contribution of intelligence, including that from civilian agencies. Later, a similar closeness was forged between Whitehall's foreign and defence policy-makers and the intelligence chiefs, not least from having to argue out their disagreements to reach a consensus on JIC papers. Finally, the JIC was the first example of the development of a governing body for a national intelligence community, overseeing the interactions between individual agencies and departments, liaising with overseas services, establishing requirements for intelligence, and assessing performance.

The JIC achieved some notable successes but also suffered from some serious failings. Ironically, perhaps, the major factors leading to its achievements were mirrored by the factors contributing to its shortcomings. Its performance was a natural consequence of a committee based on consensus, interdepartmental working, and operating at the interface between the worlds of intelligence and policy.

What was life like on the JIC at this time? A fascinating glimpse into this is provided by Chester Cooper, an American representative in London in the mid-1950s, one of whose tasks was to act as liaison with the JIC. 
Occasionally, Cooper would be asked to attend a JIC meeting, and in his memoir he recalls the first time he did so:

I was ushered into a gloomy, crowded, and cluttered conference room dominated by a table covered with a green, tea-stained baize cloth. A dozen or so men were slumped in chairs at the table or haphazardly seated around the room ... the owlishlooking man next to me (who mumbled "economist, JIB" when we were introduced) was thoughtfully absorbed in a Greek pentameter he was composing. The navy commander on my other side was dozing ... the door flew open and someone shouted, "240 for 6!" I heard cheers and groans. The intruder slammed the door behind him. I barely had a chance to make my profound contribution ... when there was a gentle knock on the door. The navy officer stirred himself, opened the door, and happily announced, "Elevenses!" Tea and biscuits were passed around. And then, once again, the door swung open and the mysterious interloper yelled, "310 for 8 !" ... I quickly learned that my first impression of this group was completely wrong. Yes, they were laconic. Yes, cricket, elevenses, afternoon tea, and Greek pentameters were nontrivial considerations. ... But, as I was soon to discover, they were bright ... they were also serious and hardworking. ${ }^{16}$

If Cooper had been startled by his first experiences of London, then it is fair to say that his British counterpart in Washington had a similar baptism:

I was introduced to each individual member by the Chairman. ... Thereafter the members sat down removing what clothing they thought fit. The gentleman on my right removed his shirt and vest and remained clad in a pair of bright red braces depicting a pair of very undressed ladies. The chair on my left was empty. The late arrival sat down and apparently did not feel the heat as he retained his hat and coat throughout the proceedings. More than half the members sat through-out with their feet on the table. You can imagine my feelings when I thought back on the meetings in the JIC in London! 
The significance of these two quotes highlights a number of points. Firstly, the difficulty (these exceptions aside) in finding anecdotal evidence about life on the JIC. Secondly, it highlights the importance in focussing on the individuals present on the Committee, something sorely lacking from previous accounts. Thirdly, it touches upon one of the most difficult issues to overcome in the clearance of the first volume; namely, not being able to officially reveal from which organisation US representatives attending the JIC were attached.

There are two important questions that emerge from the first volume of my Official History: 1) Did intelligence demonstrably influence policy? and 2) How important was the JIC specifically.

Speaking generally, over the twenty-year period, the Committee's performance in steadying the Whitehall ship in rough water was effective. Whilst its strategic forecasting sometimes failed, its operational analyses of the resulting situation were generally accurate, if sometimes coloured by seeing the influence of Moscow in the Middle East and Far East as greater than it probably was. The inherent difficulties of trying to avoid surprise, of producing predictive assessments, and of attempting to impose a rational explanation of events only dimly perceived pose epistemological problems of the highest order. The performance of the JIC cannot solely be judged by how often it was surprised by dramatic events. It is also important to 
recognise that the JIC made an important contribution to day-to-day planning and policy.

The JIC itself was an unrivalled success. In essence, in the 1950s it was carrying out four main functions:

i) producing joint, interdepartmental assessments;

ii) guiding the national intelligence effort by considering, at a senior level, the annual requirements for intelligence, and overseeing intelligence liaisons and other community issues;

iii) helping to bring together the resource requirements of the intelligence agencies, and lobbying on their behalf for greater funds;

iv) and exercising a responsibility for the security of sensitive material.

Beyond this, however, was the broader value increasingly derived by the UK from having such a variety of senior people from the worlds of policy and intelligence sit down around a table once every week, argue their way to consensus, and have to "dip their hands in the blood of the assessments."17

In conclusion, is it possible to escape the subjectivity of the Whitehall devil? The simple answer is yes. The Cabinet Office contracts for Official Historians make it explicit that the interpretation is the historian's alone, and that their control is limited to security. Furthermore, an advisory board ensures that objectivity and analytical rigour are maintained throughout. In 1962, President Kennedy, commenting on the Foreign Relations of the United States series, said that "the effectiveness of democracy as a form of 
government depends on an informed and intelligent citizenry. ${ }^{18}$ The Official History series is part of this tradition. To conclude, almost 50 years ago, D. C. Watt wrote that "the [official] historian is among things the custodian of the national memory. It is his responsibility to see that memory is kept as free as possible from the distortions of distance in time from the events remembered, of imperfect biased recollection, and of prejudice or ignorance. ${ }^{19} \mathrm{I}$ could not agree more. 
1 In fact, the Cabinet Office's relevant webpage no longer works:

http://www.cabinetoffice.gov.uk/publicationscheme/published information/1/officialhistory.aspx (accessed 20 March 2018), though an archived version is accessible:

http://webarchive.nationalarchives.gov.uk/20080205143007/http://www.cabinetoffice.gov.uk/pu blicationscheme/published information/1/officialhistory.aspx

2 An earlier version of this article appeared on the RCUK website: "Partnership for Conflict, Crime and Security Research," http://www.paccsresearch.org.uk/blog/writing-the-official-history-of-thejoint-intelligence-committee/

3 Cited in Owen Chadwick, Acton and History (Cambridge: Cambridge University Press, 1998), 29. 4 Herbert Butterfield, "Official History: Its Pitfalls and Criteria," Studies: An Irish Quarterly Review 38:150 (1949): 129-44.

5 Michael Bentley, The Life and Thought of Herbert Butterfield: History, Science and God

(Cambridge: Cambridge University Press, 2011).

6 Hugh Trevor-Roper, "Hitler: Does History Offer a Defence?," Sunday Times (12 June 1977).

7 Rodney Lowe, "Official History," Making History, 2008,

http://www.history.ac.uk/makinghistory/resources/articles/official history.html

8 Both produced their accounts in much the same way I did (e.g., full access with a sensitive draft then reviewed for clearance). One not-too-subtle difference concerned the fact that as authorised, rather than official accounts, they could break the Whitehall publishing deal with Routledge.

9 Importantly, in announcing its decision, GCHQ also mentioned that it would be "giving as many source documents from the history as we can to the National Archives." See

https://www.gchq.gov.uk/news-article/gchq-celebrate-centenary-2019 (accessed 20 March

2018). On the more limited access, see http://www.historyandpolicy.org/opinion-

articles/articles/gchq-a-new-authorised-history

10 For a longer, albeit broader overview, see Richard J. Aldrich, Rory Cormac, and Michael S. Goodman, Spying on the World: The Declassified Documents of the Joint Intelligence Committee, 1936-2013 (Edinburgh: Edinburgh University Press, 2013).

11 For some detail on these, see Rory Cormac, Confronting the Colonies: British Intelligence and Counterinsurgency (London: Hurst, 2013).

12 Brian Stewart, Scrapbook of a Roving Highlander: 80 Years Round Asia and Back (Newark, UK: Acorn Publications, 2002), 260.

13 This is rumoured to have been the view of the Chief of SIS. See Michael Herman, Intelligence

Power in Peace and War (London: IISS, 1996), 386.

14 For more detail, see Cabinet Office, Knowledge and Information Management Unit, Notes on the Central Intelligence Machinery Division of Cabinet Office Records and Other Intelligencerelated Cabinet Office Records, (Revised: 2 November 2010),

https://www.gov.uk/government/uploads/system/uploads/attachment data/file/60940/notes-oncim-division.pdf

15 This is based upon the research and experience of writing Goodman, The Official History of the Joint Intelligence Committee: Volume I, From the Approach of the Second World War to the Suez Crisis (London: Routledge, 2014).

16 Chester L. Cooper, In the Shadows of History: 50 Years Behind the Scenes of Cold War Diplomacy (New York: Prometheus Books, 2005), 137-8.

17 See Goodman, Official History of the Joint Intelligence Committee: 424.

18 Cited in Denys P. Myers, "Publication and Declassification of Records," The American Journal of International Law 56, no. 1 (1962): 158.

19 Donald Cameron Watt, "Foreign Affairs, the Public Interest and the Right to Know," Political Quarterly 34 (1963): 123. 